This is the peer-reviewed version of the article

Ejdus, F. (2018). Critical situations, fundamental questions and ontological insecurity in world politics. Journal of International Relations and Development, 21(4), 883-908.

https://doi.org/10.1057/s41268-017-0083-3

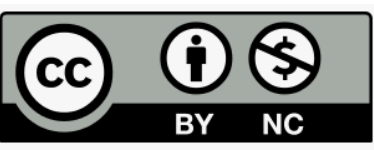

This work is licensed under the Creative Commons Attribution-NonCommercial 4.0 International license 


\section{Critical Situations, Fundamental Questions and Ontological Insecurity in World Politics}

The central premise of Ontological Security Theory is that states are ready to compromise their physical security and other important material gains in order to protect their ontological security. While extant studies have primarily focused on how states defend or maintain their ontological security, little attention has been paid to critical situations that make states ontologically insecure in the first place. Drawing on the work of Anthony Giddens, I conceptualize critical situations in world politics as radical disjunctions that challenge the ability of collective actors to 'go on' by bringing to the realm of discursive consciousness four fundamental questions related to existence, finitude, relations and autobiography. The argument is illustrated in a case study of ontological insecurity produced in Serbia by the secession of Kosovo.

Keywords: ontological security, critical situations, fundamental questions, discourse, Serbia, Kosovo

\section{Introduction}

The central assumption within the realist canon of International Relations (IR) is that the primary goal of states is to achieve physical security - defined in terms of physical survival and power. This has been challenged by Ontological Security Theory (OST) which is based on a premise that actors in world politics are often ready to compromise physical security and other important material gains in order to protect their sense of continuity in the world. This insight has been used to shed a new light on a variety of 
other concepts in IR such as the security dilemma, securitization, security communities or conflict resolution and has informed numerous empirical investigations. The ontological security argument has also been a subject of all pervasive debates in IR about the unit of analysis and the agency/structure problem. However, this literature has not sufficiently discussed critical situations which push collective actors into the state of ontological insecurity in the first place. In fact, we currently have few conceptual tools in IR to identify and analyse critical situations. As a result, the conceptual distinction between ontological security and ontological insecurity remains elusive.

This article fills this gap by proposing a conceptual framework to study ontological insecurity and critical situations. By drawing on the work of Anthony Giddens, I define ontological security in world politics as the possession on the level of the unconscious and practical consciousness, answers to four fundamental questions that all polities in some way need to address. These questions are related to existence; finitude; relations and auto-biography. Collective actors become ontologically insecure when critical situations rupture their routines thus bringing fundamental questions to the level of discursive consciousness. Their inability to 'bracket out' fundamental questions produces anxiety and a loss of agency. I exemplify my theoretical claim with a case study of Kosovo's secession from Serbia in February 2008. The case clearly demonstrates that Kosovo's secession was a critical situation as it brought to the fore all four aspects of ontological security in Serbia.

The article unfolds as follows. I begin by briefly reviewing the literature on ontological security in IR with the aim of shedding the light on an important lacuna related to the analytical treatment of critical situations. In the second section, I draw on the work of Anthony Giddens to develop the concept of critical situations through translation of 
four fundamental questions into the field of IR. In the final section I illustrate my theoretical argument with a case study of ontological insecurity generated in Serbia by Kosovo's secession in February 2008.

\section{Ontological Security Theory: The Story to Date}

The concept of ontological security was first developed in psychology within the Object Relations Theory (Erikson 1968; Laing 2010). After Anthony Giddens imported the concept into sociology (Giddens $1984 ; 1990 ; 1991)$ it quickly spread across the social sciences (Silverstone 1993; Cohen and Metzger 1998; Dupuis and Thorns 1998; Brown 2000; Hiscock et al. 2002; Noble 2005; Vigilant 2005; Padgett 2007; Skey 2010; Hawkins and Maurer 2011). In a nutshell, ontological security represents a basic need for predictability of social order and for biographical continuity. It is maintained through routinisation of every-day life, which helps actors create a 'protective cocoon' and 'bracket out' fundamental anxieties (Giddens 1991: 44). ${ }^{1}$ Ontological security is unmade by critical situations, defined by Giddens as 'a set of circumstances which for whatever reason - radically disrupt accustomed routines of daily life' (Giddens 1979: 124).

Ontological security was imported into IR by two generations of scholarship. The first generation, developed during the 1990s, imported the concept of ontological security into the field of world politics without building a brand new theory or empirically testing its explanatory potential (Wendt 1994; Huysmans 1998; McSweeney 1999). The second generation of scholarship started to emerge in the 2000s, when more systematic efforts were invested in theory building and empirical case studies, giving rise to what is known today as OST (Kinnvall 2004; Mitzen 2006b; Steele 2008b; Delehanty and Steele 2009; Browning and Joenniemi 2010; Van Marle and Maruna 2010; Zarakol 
2010; Croft 2012a; Kay 2012; Lupovici 2012; Alexandra Innes and Steele 2013; Chacko 2014; Gustafsson 2014; Rumelili 2015a, 2015b; Subotić 2015). The limited scope of this paper cannot do justice to all discussions informed by OST. Instead, I will briefly overview two central and closely interrelated debates in OST.

The first debate in OST is about the question of who is the ontological security seeking entity. It is essentially a debate about the appropriate unit of analysis between statecentric and individual-centric perspectives. Although originally developed in social psychology and later sociology to refer to individuals, OST in IR has from the very outset been applied to states. Drawing on the state-as-actor argument in IR more generally (Wendt 2004), Mitzen, Steele, Zarakol and others have anthropomorphised collective actors such as states and have treated them as the unit of analysis within OST (Mitzen 2006b; 2006a; Steele 2007a; 2008a; Zarakol 2010, Rumelili 2015b). This approach, which I also adopt in a case study on Kosovo secession presented below, has been critiqued by a number of authors (Krolikowski 2008; Roe 2008; Abulof 2009, 2015; Croft 2012b). Alana Krolikowski, for example, has argued that 'resorting to the assumption of state personhood obscures important aspects of how the state, as an evolving institution, affects individuals' sense of ontological security' (Krolikowski 2008: 111). Similarly, Paul Roe argues that just because states are providers of individual ontological security, it doesn't follow that like persons, states too can have the need to be ontologically secure (Roe 2008: 785).

Closely related but still a distinct debate in OST has been about the source of ontological security. In the words of Ayşe Zarakol, this debate, derivative of a wider agency/structure problem in IR, has been revolving around the following question: 'Are interactions and the international environment the main source of ontological anxiety for a state, or are the insecure interactions merely a consequence of the state's own 
uncertainty about its own identity?' (Zarakol 2010: 6). Zarakol discerns three distinct approaches to the agency/structure problem in OST. The first approach, adopted by Jennifer Mitzen, is social for it conceptualizes collective identity as being exogenously constructed through routinised relationships of states with their significant others (Mitzen 2006b: 355-359). The second approach, which Zarakol calls individualistic is exemplified by the work of Brent Steele and is also followed in the case study discussed in the second part of this article. It looks at how biographical continuity of states gets constructed internally through what Steele terms 'dialectics of the Self' (Steele 2008b: 32, 50). Finally, Zarakol identifies the third, so-called middle-ground approach, which departs from an assumption that 'neither a fully intersubjective approach nor one that focuses solely on the reflexive construction of self-identity captures the full picture in either case' (Kinnvall 2004; Zarakol 2010: 8).

The above sketched debates significantly expanded our understanding of who can be treated as an ontological security actor and where the sources of ontological security are to be found. However, the extant literature has largely remained silent on the issue of critical situations which produce ontological insecurity of collective actors in the first place. One of the very few authors who has reflected on the role of critical situations is Brent Steele. Drawing on Giddens, Steele argues that critical situations are unpredictable events that affect large number of individuals, catch state agents off guard and disrupt their self-identities (Steele 2008b: 12). Moreover, he posits that it is irrelevant whether researcher decides if an event is a critical situation; what matters is whether policy makers interpret them as such (Steele 2008b: 12). Finally, critical situations are not objective facts, but as Steele has pointed out, they are social constructions produced in the very process of interpretation (Steele 2008b). 
While I fully concur that critical situations are radical and socially constructed disruptions of self-identities, I argue that they are more than that. In fact, such conceptualization of a critical situation is so wide and elastic that most if not every crisis in world politics can easily fit into this definition. For example, it could be argued that every terrorist attack is usually unpredictable, affects large number of individuals, catches a state off guard and disrupts self-identity narratives. And yet, if every crisis can be treated by analysts as a critical situation, the concept of ontological (in)security loses analytical sharpness and an important part of its value to IR theory. In order to make the concept of critical situation and ontological insecurity even more specific, in the next section I return to the work of Antony Giddens and his notion of fundamental questions which lie at the core of ontological (in)security.

\section{Fundamental Questions and Critical Situations}

What does it mean to be ontologically secure? According to Giddens, 'To be ontologically secure is to possess, on the level of the unconscious and practical consciousness, answers to fundamental existential questions which all human life in some way addresses'. These fundamental existential questions relate to Existence and being; Finitude and human life; The experience of others and The continuity of selfidentity (Giddens 1991: 47). As he noted, 'To live our lives we normally take for granted issues which, as centuries of philosophical enquiry have found, wither away under the sceptical gaze' (Giddens 1991: 37). In other words, in order to be ontologically secure, agents have to be able to 'bracket out' these questions through routines of daily life thus building trust into constancy of their social and material environment and fending off existential anxieties. If unable to put aside these existential trepidations related to death, transience of life and continuity of the self and others, individuals simply cannot 'go on' with their daily life. 
Ontological insecurity, on the other hand, is a result of critical situations, circumstances of radical and unpredictable disjuncture 'that threaten or destroy the certitudes of institutionalised routines' (Giddens 1984, 62). Critical situations remove the protective cocoon created by routines and move fundamental questions, previously taken for granted, into the realm of discursive consciousness. The result is the 'flooding through' of shame and guilt from the unconscious mind (ibid. 57). The sudden inability of agents to 'go on' by relying on the unspoken know-how unleashes an upsurge of anxiety expressed in regressive modes of behaviour followed by attempts to re-establish routines and regain cognitive control over the changed environment (ibid, 64). In these 'faithful moments' as Bahar Rumelili calls them, 'anxieties can no longer be controlled' and 'ontological security comes under immediate strain' (Rumelili 2015: 11).

The distinction between discursive consciousness, practical consciousness and unconsciousness is of paramount importance here (Giddens 1984, 41-45). Discursive consciousness is the ability of actors to verbally express their actions. Practical consciousness, crucial for the maintenance of ontological security, is tacit knowledge about how to 'go on' without a need to express it discursively. Between practical and discursive consciousness there is a free flow of information. When asked to give discursive expression of something which is based on background knowledge, such as driving a car or practicing table manners for example, agents are more or less able to do it but they don't need much knowledge to carry out a competent performance. Finally, unconsciousness includes cognitions which are 'either wholly repressed from consciousness or appear in consciousness only in distorted form' (Ibid. 5). Unlike practical and discursive consciousness, the unconscious mind is therefore separated from the previous two with a bar of repression. 
The starting point of this paper is that critical situations can also affect collective agents. However, in contrast to individual experience of anxiety that doesn't have to be expressed discursively, I posit that when collective actors are concerned, anxiety outbursts are performed through a public discourse on fundamental questions. Several studies on ontological security in IR have made a passing reference to this feature of ontological security as the ability to 'bracket out' fundamental questions in order to 'go on' with daily unfolding of international life (Kinnvall 2004: 759; Krolikowski 2008: 111; Steele 2008b: 51). However, none of these studies delved deeper into what these questions are, what is their relation with critical situations and how can all this be translated into the field of world politics. In the rest of this section I intend to bridge this gap.

The first fundamental question is related to 'existence and being' that, according to Giddens, is about an 'ontological framework of external reality' (Giddens 1991: 48). This awareness 'of being against non-being' lies at the core of human freedom that generates anxiety. Giddens writes that answers to this fundamental question (like all others) are lodged at the level of practical consciousness. In pre-modern contexts, it is tradition that provides answers to this existential question and creates a sense of firmness of the world. In the context of high modernity, individuals can try to rely on tradition but this will not provide them with a safe ground. Consequently, they have to continuously reflexively reorder their activities in light of new information. ${ }^{2}$

I posit that collective actors in world politics also need to have trust in the continuity of their external environment. The society of states, with all its traditions and institutions, offers one such ontological framework for states (Bull 1977). To be ontologically secure in world politics, polities need to possess a practical understanding of what to expect from international society and build a sense of place in the existing order. To 
feel at home in international society is a precondition of states' ontological security. The importance of home and dwelling to freedom from anxiety and ontological insecurity has been well documented in psychology and social theory (Saunders 1989; Dupuis and Thorns 1998; Young 2000; Padgett 2007). For individuals, home provides 'a site of constancy in the social and material environment' (Kinvall 2004: 747). For polities, to feel at home in international society provides them with a sense of place in the international order and therefore a certain degree of cognitive control over their regional and international environment.

Bracketing out the fundamental question is accomplished through routinisation of what the English School calls the primary institutions of international society, 'deep and relatively durable social practices' such as diplomacy or international law that define legitimate behaviour and build the shared identity of states (Buzan 2014, 17). But the trust in durability of the secondary institutions of international society, such as security regimes or international organizations, can also inoculate states from existential anxieties. 'States invest in international security institutions', argue Berenskoetter and Giegerich, 'because they enable states to gain (and sustain) ontological security by negotiating a shared sense of international order with friends' (Berenskoetter and Giegerich 2010: 410). Taking part in these durable practices of international society provides constancy and thus helps contain although falling short of fully overcoming the chaos that is lurking below the surface of everyday unfolding of world politics.

Critical situations are generated by radical (real or perceived) ruptures in established routines of international society. As a result, the agent is disoriented, overwhelmed by 'the anxiety of meaninglessness' and 'the loss of ultimate concern' (Tillich 2000: 47, Rumelili 2015b: 12). Power transitions in the international system can engender ontological uncertainty even for the most powerful states that are fully integrated into 
the international society (Chacko 2014). Nevertheless, states that are suspended in the outer tier of the society of states are much more vulnerable to ontological insecurity (Neumann and Welsh 1991; Neumann 2010). Even memories from past exclusion from international society can provide fuel for the construction of critical situations. As Zarakol forcefully claimed, intersubjective pressures and stigmata exerted in the past by 'civilized' society of states become with time an integral part of late entrants' selfidentity with significant consequences for their ontological (in)security (Zarakol 2010). Rogue states such as North Korea, entirely ostracized from international society, face even greater intersubjective pressures. Ontologically vulnerable actors can try to routinise their subaltern position in the world through victimization narratives and build their self-identity upon this feature. However, their anomic position and the relentless lack of trust in the world will occasionally fuel erratic outbursts of anxiety followed by defensive measures. These may wrongly appear to an outside observer as irrational behaviour, but they are in fact a form of ontological self-help.

The second fundamental question is about 'finitude and human life'. As Giddens notes, 'here there is also a fundamental temporal dimension, in the guise of human finitude as compared to temporal infinity or the "eternal" (Giddens 1991: 48-49). While the previous question was about the awareness of the self and of external reality, this one is about agents' awareness of their own finitude and the fear of the unknown that death brings. The anxiety about death is not a simple fear of dying which is directed towards particular life-threatening objects, but rather a deep unease about its indeterminacy (Tillich 2000: 42; Rumelili 2015b: 12). Humans find answers to this question of finitude through religious cosmologies and their storylines about cycles of life and death. Without them, the anxiety about what Kierkegaard calls 'sickness onto death' looms large (Kierkegaard 1983). 
Individuals rely on states (and other polities) as ontological frameworks for mediating death and coping with its indeterminacy. By constructing enemies and dangers, states help individuals transcend their anxiety about the unknown into 'a fear of the concrete enemy or danger' (Huysmans 1998: 237). But finitude is not only the concern of individuals. Polities are indeed by default much more durable than humans, but they are not immortal either. Given their central role in mediating individual anxieties about death, even the slightest prospect of their dismembering may induce deep unease at the collective level. The anxiety about finitude should be distinguished from both fear of physical survival and societal security concerns. While their referent objects are different, physical and societal security are both oriented towards objectified threats that can be known and repelled. ${ }^{3}$ Anxiety about finitude, on the other hand, is disconnected from any particular threat and stems from the unknown and the indeterminate. Although polities may more or less successfully assuage their anxiety about finitude through the construction of concrete threats, these two concerns nevertheless remain to be of an entirely different order.

To be sure, collective actors are less concerned about the question of finitude then are individuals. This is especially the case with nations as the very condition of their existence is a belief in a trans-historic link between 'time immemorial' and 'eternal future' (Anderson 2006). However, as Uriel Abulof points out, some nations are less confident than others in their claim to immortality, while a minority of them - whom he calls 'small peoples' are in a permanent fear of extinction (Abulof 2009: 229). One of his examples are the Israeli Jews, the 'ever dying people' perpetually obsessed with the prospect of their own extinction. The list could also be expanded to include all 'mortal nations' that doubt their 'past, their future, or both' (Abulof 2015: 18). These 'mortal nations' usually incorporate fatalistic future self-projections into the narrative 
of the Self and use it as a source of ontological security. While anxiety of death is an inescapable feature of the human condition, these 'mortal nations' are less capable of coping with it. In these polities, anxiety about political finitude always lurks. Critical situations kick in when the threats amass and the 'discourse of ontological insecurity transpires' (Abulof 2015, 38). ${ }^{4}$

The third fundamental question is related to 'the experience of others' or 'how individuals interpret the traits and actions of other individuals' (Giddens 1991: 55). Here Giddens draws on insights reached by Object Relations Theory, a psychoanalytic school developed in the 1940s. One of the main concerns of Object Relations Theory was how the self is developing through dynamic relations with others, especially during infancy. Eric Erikson used the term 'ontological security' to denote existential trust in the continuity of relationships with significant others (Erikson 1968). Taking cues from the Object Relations Theory, Giddens concurs that 'confidence in the reliability of persons, acquired in the early experiences of the infant' is the backbone of basic trust and ontological security later in life (Giddens 1991: 38).

In world politics, this fundamental question is about the ability of polities to maintain stable relations with their significant others. As Jelena Subotić remarks: 'it is not enough for states to feel secure in their view of self; they also need to feel secure in the company of other states' (Subotić 2015: 7). The relational aspect of ontological security is obviously closely intertwined with the question of existence. However, there is a subtle difference between the two. While the sense of place in the existing order is based on routinisation of certain practices of international society such as international law, the relational aspect of ontological security is about the constancy of relationships with a particular set of significant others. 
As the other is constitutive of the self (Campbell 1992; Neumann 1999), disruption of routinised self/other relationships is by default going to impinge upon the relational aspect of ontological security. Jennifer Mitzen has compellingly demonstrated the relevance of stable relationships with significant others, either cooperative or conflictual, for ontological security processes (Mitzen 2006). While the existence of an enemy threatens physical security, its disappearance may produce what Bahar Rumelili has called 'peace anxieties' (Rumelili 2015b). When the Soviet Union collapsed in 1991, the very idea of 'the free world' saw the same fate. Similarly, ontological insecurity produced in the West by the end of the Cold War triggered a quest for a new opponent. The September 11 terrorist attacks provided an opportunity for the United States to rediscover radical Islam as its archenemy and reinvent itself in the War on Terror (Campbell 1992; Qureshi and Sells 2003).

Although less studied in IR, friendships also 'tame anxiety' as they stabilize meaning, enable learning and burden sharing but they also increase mutual vulnerability (Berenskoetter 2007). The loss of a friend with whom a polity cultivates a 'special relationship', or even identifies, can also create critical situations and trigger deep sense of ontological insecurity. In her study of the Suez crisis and temporary rupture in Anglo-American alliance, Janice Bially Mattern writes that 'preserving their Self meant sustaining the narrative of the Special Relationship' (Mattern 2005: 15). When friends are lost, collective identity of polities is questioned. In critical situations, previously bracketed and taken for granted issue of self/other relationships bursts into the public discourse. As a result, polities are overwhelmed by anxiety and disoriented especially in their foreign policy. 
Finally, the fourth fundamental question, which needs to be 'bracketed out' as a precondition of ontological security, is related to 'the continuity of self-identity' or 'the persistence of feelings of personhood in a continuous self and body' (Giddens 1991: 55). Self-identity is not a collection of objective traits of a person but rather 'the self as reflexively understood in terms of her or his biography' (1991: 53). Agents with stable self-identity can sustain biographical continuity across time and space through reenactment of their daily routines. In contrast to them, agents with a fractured selfidentity have a harder time sustaining their autobiographical narratives. In the case of critical situations, this results in a paralysing inability to act in any purposeful way. In contrast to the relational aspect of ontological security, which is about external and social aspects of self-identity, what Herbert Mead calls 'Me', this biographical aspect is about internal and reflexive 'I' (Mead 1934).

In world politics, in order to be ontologically secure, polities too need to 'bracket out' the question of 'the continuity of self-identity'. Autobiographical narratives are constructed as continuous in time and space (Berenskoetter 2012). Whereas in time, biographies unfold through past experiences or future visions, in space they situate the self around imaginary centres but also in exploration of new horizons (Ibid. 276). If polities are not able to synchronize their past or current activities with their autobiographical narratives, the fundamental question of 'the continuity of selfidentity' bursts into the discursive domain and if not competently answered, produces shame (Steele 2008b: 52-57) and what Tillich calls 'the anxiety of guilt and condemnation' (Tillich 2000: 51, Rumelili 2015:11). 
The paramount biographical narrative for Westphalian states pertains to their corporate identity as sovereign entities (Wendt 1999: 224). In order to be able to 'go on' in world politics, states have to take for granted their own sovereignty. Individuals who decide on behalf of states know, at the level of practical consciousness, how to be sovereign through everyday practices such as diplomacy, military drills or border patrols to name just a few. It is only if those who represent states cannot sustain those practices that they bring the issue of sovereignty back to the level of discursive consciousness, resulting in the creation of an ontological insecurity problem.

In addition to being sovereign, states can also have a number of other narratives about the self that can only be maintained through certain practices (Ringmar 2007; Steele 2008b: 114-148). Brent Steele showed how the German ultimatum of August 1914 created a critical situation for Belgium. Contra realist expectations that states put physical security before anything else, Belgium eventually decided to reject the German request for free passage through its territory and trumped physical security in order to defend its honour as a military neutral state (Steele 2008b: 94-114). Several scholars have pointed out how the interpretation of $9 / 11$ attacks as an assault on 'the way of life' disrupted ontological security in the US (Zaretsky 2002; Ruby 2004; Epstein 2007). In certain situations which Lupovici calls 'ontological dissonance', multiple state identities are simultaneously threatened while measures to defend them are contradictory and self-inflicting (Lupovici 2012).

Imagined communities, such as nations, which may or may not coincide with the boundaries of the Westphalian state, also need to bracket out the fundamental question of self-identity in order to 'go on'. By default, nations are held together by master- 
narratives about the continuous self, moving through time and space. This imagined self stretches from the time immemorial, golden era and common ancestors through chosen glories and shared traumas to the present, which periodically returns to yet another critical juncture on the path towards eternal future. For example, by reiterating the story that modern Macedonians descend from Alexander the Great, contemporary Macedonian nation-builders are recursively reproducing a particular biographical narrative about a trans-historic self which is attached to a certain space. On the contrary, casting a doubt on this trans-historic unity automatically disrupts ontological security and expands the space for fundamental political contestations. Recent debates about the modern invention of the Jewish nation and the land of Israel and its direct repercussions for the legitimacy of Israeli policies in the West Bank, as well as the public outcry it provoked in Israel and across the Jewish Diaspora, is an illustrative case in point (Sand 2010; 2012). As Uriel Abulof points out, 'historical novelty is a grave threat to ethnic ontological security, since it undercuts the primordial claim' (Abulof 2015: 38-9). In critical situations, amassed inconsistencies in autobiography are brought to the forefront of public discussion pushing nations into the paralysing vortex of shame and self-doubt.

The key feature of critical situations is the inability of collective actors to bracket out the above described fundamental questions about unreliability of international order, finitude of polities, impermanence of relationships and inconsistency of collective autobiographies. They are usually created by unpredictable events that break established routines and prompt polities to seek, more or less skilfully, answers to fundamental questions at the level of discursive consciousness. In critical situations, as Rumelili points out, 'anxieties that can no longer be contained by existing social and 
political processes are unleashed in varying ways and varying degrees' (Rumelili 2015b: 12).

Critical situations and responses to them vary from case to case. In some cases, critical situations will be of such magnitude that all four aspects of ontological security will be undermined involving discursive interventions of top political leadership. In others, the disruption will be of lower intensity and may not impinge on all four fundamental questions or involve the entire political establishment. Either way, the flooding through of collective anxieties debilitates (to varying degrees) collective agency and leads to seemingly regressive, hysterical or schizophrenic behaviour. The defence measures taken to mitigate ontological security were studied by others and fall beyond the scope of the theoretical contribution that this article seeks to make. Suffice it to say that in some situations actors will rigidly attach to old routines, even if they are self-inflicting (Mitzen 2006). In others, they will selectively use identity narratives to mitigate anxiety (Subotić 2015). In cases when several identities are simultaneously disrupted, states can resort to avoidance (Lupovici 2012) or denial (Zarakol 2010). The choice of the response will depend on the severity of the crisis and available options.

Critical situations are complex phenomena in which all four aspects of ontological security are usually closely intertwined. To begin with, all fundamental questions are central to the narrative of the Self. To feel at home in international society is closely related to the biographical continuity of a state as a sovereign actor with a particular type or role identity (e.g. super power democracy). Moreover, states' experience with international society is inextricably linked with self/other relationships, both being soft wired into biographical narratives. Finally, polities' concern with their finitude is 
inextricably linked with their relationship with others or with polities' position within the international society. However, the move to analytically disentangle ontological insecurity into four fundamental questions has a double heuristic purpose. First, it allows us to keep a holistic view proposed by Giddens that incorporates different aspects of ontological security without prejudice to an otherwise highly relevant agency/structure debate. Second, by deliberately oversimplifying complex situations of ontological insecurity in world politics into four ideal-typical aspects, we are able to better understand particular outcomes (Jackson 2011, 142). In the following section, I show the heuristic value of this analytical move in the case of Kosovo's secession from Serbia.

\section{Kosovo's Secession and Serbia's Ontological Insecurity}

On 17 February 2008 the province of Kosovo unilaterally declared independence from Serbia. It has been argued before that the crisis over independence created not only physical insecurity for Serbia but also 'a sense of ontological insecurity' (Subotić 2015, 11). However, previous studies have not delved into a more detailed and comprehensive analysis of what makes situations - such as the declaration of independence - critical, resulting in a deep ontological insecurity for collective actors. In this case study, I suggest that the unilateral declaration of independence was a critical situation for Serbia as it thrust into public discourse all four fundamental questions discussed in the previous section. With time, as the case study shows, new routines helped to bracket out some of the fundamental questions and thus assuage anxiety. However, prolonged political uncertainty over the Kosovo conundrum has continued to hamper the Serbian nation-state in fully recovering its trust in the continuity of both self and others in world 
politics. Before I move to the critical situation set into motion by the declaration of independence, a brief discussion about the historical context is in order.

\section{The historical context of secession}

Since the outset of Serbia's modern nation building in the $19^{\text {th }}$ century, Kosovo played an important role as its 'core territory', defined by George White as the territory of paramount importance for national identity (Emmert 1981; Anzulović 1999; White 2000; Bieber 2002; Djokić 2009). This is based on the mythical Battle of Kosovo that took place on June 28, 1389 between the Serbian Christian forces and the Ottoman Turks. The outcome of the battle is somewhat unclear and the Serbian medieval state continued to exist as an independent entity until 1459. However, the Kosovo battle has been inscribed in the collective memory as the biggest catastrophe ever to befall Serbia. From the late $18^{\text {th }}$ century onwards, the Kosovo myth was used by Serbian nation builders to 'wake up' the nation from its centuries-long slumber and set if free from Ottoman slavery. Although the majority of Kosovo's population was (and still is) Albanian, Muslim and most importantly hostile to the Serbian rule, Kosovo was construed in the late $19^{\text {th }}$ century as the Holy land of the Serbian people. This was bound to be an uneasy affair. I will not repeat the well-known history of the inter-ethnic conflict that culminated in 1999 , with NATO intervention to stop Serbia's atrocities against the Albanian population in Kosovo (Mertus 1999; Herring 2000; Judah 2002; Webber 2009). Instead, I fast forward to Kosovo's unilateral declaration of independence that set in motion the profound ontological insecurity of the Serbian nation-state, which in some respects persists until today.

After several years of unsuccessful negotiations conducted under the auspices of the United Nations (UN), Kosovo, Serbia's province since 1912, unilaterally issued a 
declaration of independence on 17 February 2008. An avalanche of recognitions followed suit, including by states that Serbia had considered its key allies. Authorities in Belgrade fiercely objected this move and labelled it a violation of territorial integrity, a breach of international law and a challenge to national identity. In spite of that, over the next few years more than half of UN member states recognized Kosovo's statehood. ${ }^{5}$ In spite of the huge international pressure to come to terms with this new reality, Serbia still remains determined never to recognize the independence of its erstwhile province whatever the consequences. Furthermore, Serbia doesn't have either a plan or economic, political or military capacities to regain control over Kosovo whose Albanian population overwhelmingly supports independence.

Costly, unrealistic and unsustainable, this policy has been puzzling to scholars. Continuity and change in Serbia's counter recognition policy have been discussed in a number of studies (Ker-Lindsay 2012; Obradović-Wochnik and Wochnik 2012; KerLindsay 2013; Hashimoto 2014; Subotić 2015). I submit that these accounts, although worthy in their own right, are incomplete without paying closer attention to the multidimensionality and comprehensives of ontological insecurity faced by Serbia as the result of Kosovo's secession. How widespread this feeling was among the general public is best illustrated by the fact that in January 2008 , a staggering $71 \%$ of Serbian citizens, anticipating Kosovo's secession, suffered from 'siege mentality', a perception that the polity is facing existential threats (Šram 2009). In the remainder of this section I will investigate which elements of ontological security were disrupted by the secession and how.

I illustrate the analysis with elite public statements made by Prime Minister Vojislav Koštunica, President Boris Tadić, Foreign Minister Vuk Jeremić, Minister of Interior Ivica Dačić, leader of the opposition and later President Tomislav Nikolić and Patriarch 
Irinej, the head of the Serbian Orthodox Church and their media coverage. Such a selection encapsulates a wide spectrum of elite Kosovo related storylines activated in the wake of the unilateral declaration of independence of Kosovo issued on 17 February 2008 and in its immediate aftermath.

\section{Kosovo's secession and Serbia's ontological insecurity}

Kosovo's unilateral declaration of independence was a critical situation that did not catch Serbia's authorities entirely by surprise but was in fact anticipated months in advance. ${ }^{6}$ The Serbian state was, however, everything but prepared for such a radical disruption that flooded the public discourse with fundamental questions thus generating anxiety, inability to 'go on' and the drive to recover old or establish new routines.

First, Kosovo's unilateral declaration of independence and international recognitions that followed shattered Serbia's ontological awareness of its external reality as firm and continuous. A sovereign country, an old European state and a founding member of the $\mathrm{UN}$, as it was often emphasized, was torn apart, while the world either stood idly by or wholeheartedly endorsed it. Serbia's leaders construed the secession as a violation of the very foundations upon which the international society was built. The fact that so many countries quickly supported Kosovo's secession particularly disturbed Serbia's sense of order in the world.

For example, anticipating Kosovo's independence, Serbia's conservative Prime Minister Koštunica delivered a speech at the United Nations Security Council in December 2007, in which he portrayed this coming ordeal using dramatic, almost apocalyptic terms:

The Destiny of my country [...] of paramount importance for the entire world [...] question above all questions [...] dangerous precedent would irreversibly challenge the 
credibility of the UN and permanently threaten the stability of the world order [...] crucial for Serbia as well as for the world organization $[\ldots]$ immense consequences not only for Serbia and the region but for peace and stability in the world (Koštunica 2008: 200-209)

Only three days before the unilateral declaration of independence in February 2008, he again warned that Kosovo's looming secession was key not only to 'the future of Serbia but for the legal order and the future of the world' (Koštunica 2008: 224). Immediately after the declaration was issued, the Prime Minister argued in his speech delivered to Serbia's Parliament on 18 February that 'yesterday's illegal act violated the UN Charter, Resolution 1244, Final Helsinki Act and all international legal norms upon which the world order is founded' (Koštunica 2008: 231). From Serbia's point of view, it truly seemed as if the world had fallen apart.

Particularly distressing was the fact that the West, where Serbia aspired to belong, by and large had strongly supported Kosovo's secession. Consequently, many leaders in Belgrade raised doubts in the very integrity of the European society of states. In a speech delivered at the European Parliament only three days after Kosovo's declaration of independence, Serbian Minister of Foreign Affairs Vuk Jeremić stated: 'I stand before you this afternoon as a proud European, and as an ashamed European' and then went on to explain:

I am ashamed not as a Serb [...] I am ashamed as a European. As someone who knows in his heart that what has been done to Serbia is a fundamental violation of the very nature of not just the international system, but of the values that hold up the European construction (Jeremić 2008). 
The loss of trust in the reliability of the international order was an important aspect of Serbia's ontological insecurity triggered by the declaration of independence, but it was not the only one.

Second, Kosovo's secession also triggered old narratives of Kosovo being Serbia's tomb, thus bringing to the foreground the question about polity's finitude. In other words, the secession wasn't seen only as undermining the fundamental principles of the domestic and international political order, but also undermining Serbia's future survival prospects. In fact, many in Serbia were engulfed with anxieties that if Kosovo would be allowed to secede, similar claims would soon appear in other parts of Serbia as well, such as Vojvodina, Preševo Valley or Sandžak.

The trope of Kosovo as the tomb of the Serbian nation is very old. When the group of Serbian nobles gathered in November 1803 to discuss ways to resist the Ottoman terror, the priest Atanasije Antonijević began his speech with the following words: 'Brothers! So many years have passed since all our glory was buried in what is for all of us a sad grave in Kosovo' (Milić 2006: 61). The priest, of course, did not have in mind the disappearance of Serbia in 1459, but the mythical battle fought in 1389. The same trope was part and parcel of the Kosovo myth throughout the $20^{\text {th }}$ century.

The prospect of Kosovo's secession triggered deep-seated anxieties about the finitude of the Serbian polity. Anticipating the collapse of the UN sponsored negotiations in December 2007, Serbia’s Prime Minister Koštunica called upon the Serbian National Assembly to adopt a Resolution on territorial integrity and sovereignty with the following words:

We have to fight and win the future of Serbia for we don't have any other way. Otherwise, somebody will tomorrow come to an idea that crippled Serbia can be further 
dismembered as one pleases. The future of Serbia is inextricably linked with the future of Kosovo (Koštunica 2008: 216).

Another key trope feeding this anxiety about finitude was the depiction of Kosovo as 'the heart of Serbia' that is being pulled out of the body politic. The metaphor was launched into the discursive space by President Slobodan Milošević some 20 years earlier, and was reactivated in the wake of the declaration of independence. The mantra 'Kosovo is Serbia' quickly engulfed public discourse including the voices from the opposition. Tomislav Nikolić, who was the nationalist leader of the Serbian opposition at the time of the declaration of independence, addressed a massive rally in Belgrade on 21 February with the following words: 'Kosovo is the heart of Serbia, and there can be no replacement for the heart' (Glas javnosti 2008). As the body cannot live without its heart, the consequence of the political usage of this metaphor was a deeply ingrained belief shared across the political spectrum that Serbia simply cannot 'go on' without Kosovo.

Third, the unilateral declaration of independence also raised the fundamental question of Serbia's relationships with its significant others in world politics. To the dismay of most, former friends, even strategic allies quickly recognized the independence of Kosovo. The most exemplary case in point was the moment when the 'brotherly' state of Montenegro did so in October 2008. This was portrayed almost univocally in Serbia as an act of yet another betrayal, while the president of the Serbian Parliament called it 'a knife in the back' (Blic 2008). Of all the countries that had recognized Kosovo, ambassadors of 'brotherly' neighbours Montenegro and Macedonia were singled out and declared personae non grata in Serbia. With each subsequent recognition, stability 
of Serbia's foreign relationships was questioned anew, thus further disrupting its ability to maintain stable and consistent relationships with its significant others.

Most importantly, the secession of Kosovo raised the question of Serbia's future relationship with the European Union. Officially, the club of then 27 states did not have a position (and still does not) on this issue due to five member states which refused to recognize Kosovo, mostly for domestic reasons (Cyprus, Greece, Romania, Slovakia and Spain). Disappointed with the fact that all other EU member states rushed to accept the new Kosovan state, Prime Minister Koštunica advocated conditioning any further steps in the direction of membership with the EU's explicit commitment to Serbia's territorial integrity. The rest of the government was against this move and the government eventually collapsed in March 2008.

State representatives also tried to make sense of the disturbed relationship with the United States. Even before the declaration, over a rather short period of time, the US morphed from an ally into the worst possible enemy as the main sponsor of Kosovo's independence. On 28 June 2007, Koštunica argued that instead of Turks, Serbia was now facing a different enemy: 'In front of the entire world a new Serb-American battle for Kosovo is now being waged. On one side there is the authority of a great power, while on the other side there is Serbia and the arguments of justice' (Balkan Insight 2007).

Kosovo's unilateral declaration of independence also confirmed old and fostered new friendships. In fact, any country that for whatever reason refused to recognize Kosovo was now regarded as Serbia's 'friend' and Russia topped the list. Expressing his gratitude for Russia's support Serbia's Foreign Minister Jeremić said in April 2011: 'This is a relationship of mutual friendship and unequivocal, unconditional mutual 
support. It is based on understanding, and in the international arena, that kind of support comes only from best friends. Today, Serbia and Russia are best friends' (B92 2011). Russian interests were ruled out: its backing of Serbia was interpreted as nothing but a selfless act of genuine brotherhood. The revised list of Serbia's friends also included five EU non-recognizers, somewhat less vocal but equally determined China, and the rest of the non-recognizing countries from the developing world. The list of 'friends' who did not recognize Kosovo, however, has been destined to shrink over time, generating a continuous ontological unease ever since.

Finally, the secession of Kosovo also raised concerns about inconsistencies in the autobiography of Serbia as a state. In the face of secession, Serbia had to first and foremost defend its credentials as a sovereign actor. Prime Minister Koštunica clearly expressed that the declaration was in a way the culmination of the illegal NATO intervention into domestic affairs of a sovereign state: 'The cruel aggression', he lamented, "which started in the evening of 24 March 1999 showed its true face on 17 February 2008' (Koštunica 2008: 241). The declaration of independence was seen as a critical situation by him and by most other representatives of the Serbian state, because it problematized something that hitherto went without saying - Serbia's self-awareness as a sovereign state. Almost a year before the declaration of independence was issued, Koštunica made it clear that the UN plan envisioning a supervised independence was impinging on Serbia's status as a sovereign state. On 10 March 2007, during negotiations conducted under the auspices of the UN in Vienna, he stated: 'This proposal, instead of solving the issue of the autonomous province of Kosovo, actually opened the issue of Serbia's status as a state, which we consider illegal and illegitimate' (2008: 116). 
Kosovo's secession was interpreted by political elites as a rupture in the biographical continuity of Serbia as a nation. Already in April 2007, Koštunica addressed the UN Security Council with the following words: 'The dignity of my country and of my people is inseparable from Kosovo and Metohija where our state, our religion, our culture and our national and state identity was born' (Koštunica 2008: 135). Three days after the declaration, he clearly spelled out what was at stake in front of several hundred thousand people gathered in downtown Belgrade on 21 February 2008:

If we as Serbs renounce Serbhood, our origins, our Kosovo, our ancestors and history - then who are we Serbs? What is our name, then? [...] They are promising us that if we recognize that we are not Serbs, we will be better off as a nation without memories and origins [...] Kosovo is the true name of Serbia. Kosovo belongs to Serbia. Kosovo belongs to the Serbian people. It was so from time immemorial. And so shall it be forever (Koštunica, 2008: 236, 7).

Prime Minister Koštunica may have been one of the most vocal leaders who advanced the idea that Kosovo connects contemporary Serbs with their ancient ancestors, but he was not alone. Virtually all decision makers in Serbia made similar justifications for why Kosovo cannot be recognized. For instance, Serbia's Minister of the Interior Ivica Dačić of the Socialist Party of Serbia cautioned:

Everyone must understand that the issue of Kosovo is very difficult for Serbia, because Kosovo represents the foundational stone Serbia was constructed on, and if that foundational stone is pulled out, then, of course, the entire story will start swaying (Quoted in Ejdus 2010).

This implied that without Kosovo, the stories about 'who we are' and 'where we come from' would no longer have any meaning. The potential collapse of the shared past 
threatened to bring about autobiographical discontinuity and triggered anxiety from 'inner death' (Laing 2010).

In order to fend off the above outlined anxieties related to existence, finitude, relations and autobiography, Serbia's leaders tried to recover the lost sense of continuity by routinizing a new master-narrative built around a defiant vow that Serbia will never recognize Kosovo, regardless of the price. In a speech delivered to Serbian students in Kosovo on 27 February 2008, Koštunica said: 'Today one can sense pride in Serbia, pride of a free nation that does not want to be subjected to violence and injustice [...] Maybe the US from its superior position of a great power thought that Serbia is a small nation $[\ldots]$ but with time they will realize greatness of Serbia's struggle for law and justice' (Koštunica 2008). According to this new narrative only if Serbia and the Serbs remain perseverant in their vow never to recognize Kosovo's independence, the polity will protect its honour and survive.

Once the public oath was given never to recognize the 'fake state of Kosovo', and became an inseparable part of the new master-narrative, collective anxieties somewhat subsided, but never fully receded into the background. State representatives continue to frequently deplore the trope of 'double standards' in international society, and the wider public shares a high level of mistrust in the international system (B92 2015). Moreover, ruminations about the potential dismemberment of Serbia continued to be perpetuated. In 2012, more than two hundred public figures signed a proclamation titled 'Serbia is under threat' in which the secession of Kosovo was interpreted as a prelude to the secession of Vojvodina and Sandžak and therefore further disintegration of Serbia (B92, 2012). The Patriarch of the Serbian Orthodox Church issued similar warnings on numerous occasions repeating that 'without Kosovo, Serbia is like a body without a head or a heart' (B92, 2014a). But if Serbs remain united and defiant never to accept 
the independence of Kosovo, he assured, one day they will return to Kosovo like the Jews 'who waited for Jerusalem for 2,000 years and finally got it' $(B 92,2013)$. The rigid attachment to this mantra and its ritualistic repetition cannot fully inoculate the polity from twin feelings of shame and anxiety and provide a permanent cocoon and a sense of calm (Solomon 2013). However, the new narrative can assuage anxieties by creating a mirage that the fate of Kosovo ultimately lies in the hands of Serbia.

In parallel to this continued rigid attachment and tautological insistence on nonrecognition, Serbia slowly adapted its practices as well. Early on after the declaration, the idea of breaking the diplomatic relationships with recognizers or suing them in front of international courts was abandoned as self-defeating. In 2010, following the advisory opinion issued by the International Court of Justice that the declaration of independence was not violating international law, Serbia accepted EU's supervisory role in the normalization of relationships between Belgrade and Prishtina. Motivated by economic and political incentives offered by the EU, Prime Ministers of Serbia and Kosovo signed a 15-point agreement on the normalization of relationships under the supervision of the EU in April 2013 (Vachudova 2014; Economides and Ker-Lindsay 2015). With this, Serbia agreed to dismantle its 'parallel structures' in North Kosovo (where Serbs are in majority) and thus cede its last remaining instruments of rule in its former province to Kosovo authorities. As a result, EU rewarded Serbia by officially opening membership talks in January 2014.

Serbia's leaders invested significant discursive effort in justifying these decisions without changing the master narrative (Subotic 2015). Nonetheless, they continue to incessantly and virtually with one voice repeat that in spite of normalization of relationships with Kosovo they will never recognize its independence. And while the EU continues to lack an official position on the independence of Kosovo, some EU 
member states have been sending increasingly direct and vocal messages to Belgrade that recognition, de facto if not de jure, will inevitably be a condition for Serbia's accession. Serbia's president Tomislav Nikolić has recently acknowledged this:

I think the most important condition for our entry into the EU will be to recognize Kosovo's independence, but Serbia will not recognize it, and never has. But, if the EU continues to insist on such a decision, it will mean that the EU does not want to see us in its ranks $[\ldots]$ no nation would agree to such a requirement. Only slaves would (B92 2014).

This policy of non-recognition of Kosovo, costly in economic and political terms and in spite of recent normalization of relationships should be understood as honour driven ontological self-help for Serbia. This is exactly the reason why expectations that Serbia will give up and recognize Kosovo in exchange for material benefits such as EU membership, are problematic. On the contrary, short of a thorough self-identity transformation, which does not seem to be in the cards at present, Serbia will most likely continue its rigid attachment to the non-recognition policy. This is the anchor that, however imperfectly, shields the state from fundamental questions initially unleashed by the critical situation generated by Kosovo's 2008 unilateral declaration of independence.

\section{Conclusion}

Scholarly debates about ontological security in world politics have largely overlooked the issue of critical situations. In this article I have made a contribution to fill that gap by conceptualising critical situations as radical disruptions which thrust fundamental questions of existence, finitude, relations and autobiography into the realms of public discourse. As a result, collective actors experience anxiety, exhibit regressive behaviour 
and attempt to restore the calm through rigid attachment to old or new routines. In the case study, I have shown that Kosovo's declaration of independence from February 2008 was a critical situation that engulfed public discourse in Serbia with all four types of fundamental questions, indicating deep ontological insecurity.

The theoretical implication of this move is to make the meaning of the terms 'critical situation' and 'ontological insecurity' more intelligible. By carefully translating additional analytical tools developed by Giddens into the field of IR, I developed a framework that allows us to identify critical situations in world politics and study them empirically in a systematic and comparative manner. While conceptualisation proposed in this article is supposed to move us closer to a better understanding of ontological insecurity in world politics, it nevertheless raises a set of additional questions and ideas for further research.

To begin with, the conceptual boundary between 'critical' and 'ordinary' situations remains far from conclusive. While I have suggested ways to delineate discursive features of critical situations, further research is needed into better understanding when and how they actually end. Also, one could plausibly argue that critical situations are relatively rare events and that collective agents seldom experience either ontological security or insecurity in absolute terms. Most polities spend most of the time muddling through the grey zone managing their low-intensity anxieties. Consequently, future research could pay more attention to that zone in-between smooth confidence and continuity of self-identity on the one hand and paralysing anxieties on the other.

Furthermore, the extant research have focused on elite perceptions in OST and I have also followed this path in the case study on Kosovo's secession from Serbia. However, more sociological research that would look into the role of both context and audience 
would significantly advance the debate. Here, ontological security theorists can draw on recent developments in securitization theory. There is a rich potential for crossfertilization between the two bodies of knowledge that has remained mostly unrealised so far.

Also, there is the issue of epistemology. The basic epistemological premise at least in this article (as well as in many other works on OST) has been that we can only understand the world if we start from the experience of social agents. In other words, it doesn't matter if we as scholars define something as a critical situation; what really matters is how social agents interpret it. However, social agents usually do not use the concepts of 'ontological security' to interpret the world, although the process of double hermeneutics may change this in the future. The question is then how far can we go in conceptually elaborating the theory without drifting away too much from the interpretivist starting point.

Finally, OST has yet to grapple with the issue of change. The inability of extant approaches to OST to deal well enough with re-routinisation, re-socialisaton and identity transformation has been partially inherited from Giddens' structuration theory. While this theoretical problem falls beyond the scope of this article, the Kosovo case study has made hints in that direction. Serbia's initial reaction to secession was rigid attachment to old routines and self-identities. As years passed by, it slowly started to change its practices and accept to normalize its relationships not only with states who recognized Kosovo but with Kosovo itself as well. This hints at the remarkable potential for resilience in the face of critical situations which has only recently started to attract scholarly attention and which could be a very productive avenue for further research on ontological security as well. 
Words: 11893

\section{References:}

Abulof, Uriel (2009) '“Small Peoples": The Existential Uncertainty of Ethnonational Communities,' International Studies Quarterly 53(1): 227-248.

Abulof, Uriel (2015) The Mortality and Morality of Nations, Cambridge: Cambridge University Press.

Adler, Emanuel and Vincent Pouliot (2011) 'International Practices,' International Theory 3(01): 1-36.

Alexandra Innes and Brent Steele (2013) 'Memory, Trauma and Ontological Security,' in Erica Resende and Dovile Budryte, ed., Memory and Trauma in International Relations: Theories, Cases and Debates, 15-30, London: Routledge.

Anderson, Benedict (2006) Imagined Communities: Reflections on the Origin and Spread of Nationalism, London: Verso Books.

Anzulović, Branimir (1999) Heavenly Serbia: From Myth to Genocide, New York: NYU Press.

B92 (2011) 'Serbia-Russia Ties "Unequivocal, Unconditional,' available at http://www.b92.net/eng/news/politics.php?yyyy=2011\&mm=04\&dd=19\&nav $\_$id=73879 (4 March 2015).

B92 (2014) 'Serbia Won't Recognize Kosovo, President Reiterates,' available at http://www.b92.net/eng/news/politics.php?yyyy=2015\&mm=05\&dd=08\&nav _id=94055 (19 November 2015).

B92 (2015) 'FM at UN: "Abolish either UNSCR 1244, or double standards,' available at http://www.b92.net/eng/news/politics.php?yyyy=2015\&mm=08\&dd=21\&nav _id=95186 (21 August 2015). 
BalkanInsight (2007) 'Kostunica: New Kosovo Battle Between Serbia and the US,' available at http://www.balkaninsight.com/en/article/kostunica-new-kosovobattle-between-serbia-and-the-us (4 March 2015).

Berenskoetter, Felix (2007) 'Friends, There are No Friends? An Intimate Reframing of the International,' Millennium-Journal of International Studies 35(3): 647676.

Berenskoetter, Felix (2012) 'Parameters of a National Biography,' European Journal of International Relations, 20(1): 262-288.

Berenskoetter, Felix and Bastian Giegerich (2010) 'From NATO to ESDP: A Social Constructivist Analysis of German Strategic Adjustment after the End of the Cold War,' Security Studies 19(3): 407-452.

Bieber, Florian (2002) 'Nationalist Mobilization and Stories of Serb Suffering: The Kosovo Myth From 600th Anniversary to the Present,' Rethinking History 6(1): 95-110.

Blic (2008) ‘Crna Gora i Makedonija priznale Kosovo,' available at http://www.blic.rs/Vesti/Tema-Dana/60288/Crna-Gora-i-Makedonijapriznale-Kosovo (4 March 2015).

Brown, William S (2000) 'Ontological security, existential anxiety and workplace privacy,' Journal of Business Ethics 23(1): 61-65.

Browning, C and Pertti Joenniemi (2010) Escaping Security: Norden as a Source of Ontological Certainty. SGIR 7th Pan-European IR Convention.

Bull, Hedley (1977) The Anarchical Society: A Study of Order in World Politics, London: Macmillan.

Buzan Barry, People States and Fear: An Agenda for International Security Studies in the Post-Cold War Era (1991) Heartfordshire: Harvester Wheatsheaf. 
Buzan Barry, Ole Wæver, Jaap de Wilde (1998) Security: A New Framework for Analysis, London: Lynne Rienner.

Buzan, Barry (2014) An Introduction to the English School of International Relations, Cambridge: Polity Press.

Campbell, David (1992) Writing Security: United States Foreign Policy and the Politics of Identity, Minnesota: University of Minnesota Press.

Chacko, Priya (2014) 'A New “Special Relationship”?: Power Transitions, Ontological Security, and India-US Relations,' International Studies Perspectives 15(3): 329-346.

Cohen, Jonathan and Miriam Metzger (1998) 'Social Affiliation and the Achievement of Ontological Security Through Interpersonal and Mass Communication,' Critical Studies in Media Communication 15(1): 41-60.

Zarakol) 'Constructing Ontological Insecurity: The Insecuritization of Britain's Muslims,' Contemporary Security Policy 33(2): 219-235.

Croft, Stuart (2012b) Securitizing Islam: Identity and the Search for Security. Cambridge: Cambridge University Press.

Delehanty, Will K and Brent J Steele (2009) 'Engaging the Narrative in Ontological (in) Security Theory: Insights From Feminist IR,' Cambridge Review of International Affairs 22(3): 523-540.

Djokić, Dejan (2009) 'Whose Myth? Which Nation? The Serbian Kosovo Myth Revisited', in Janos M. Bak, Jörg Jarnut, Pierre Monnet and Bernd Schneidmueller, eds. Uses and Abuses of the Middle Ages: 19th-21st Century, Munich: Wilhelm Fink.

Dupuis, Ann and David C Thorns (1998) 'Home, Home Ownership and the Search for Ontological Security,' The Sociological Review 46(1): 24-47. 
Economides, Spyros and James Ker-Lindsay (2015) 'Pre-Accession Europeanization': The Case of Serbia and Kosovo,' JCMS: Journal of Common Market Studies 53(5):1027-1044.

Ejdus, Filip (2010) 'That Foundation Stone of Serbia, September 6, Available at http://pescanik.net/that-foundation-stone-of-serbia/ (13 June 2016).

Emmert, Thomas A (1981) 'Kosovo: Development and Impact of a National Ethic,' in John Ackerman, Ivo Banac and Roman Szporkuk eds. Nation and Ideology, 61-86, New York: Eastern European Monographs.

Epstein, Noa (2007) 'Explaining the War on Terrorism from an Ontological-Security Perspective,' MIT International Review: 13-14.

Erikson, Erik H (1968) Identity: Youth and Crisis, New York: WW Norton \& Company.

Giddens, Anthony (1979) Central Problems in Social Theory: Action, Structure and Contradictions in Social Analysis, Berkley and Los Angeles: University of California Press.

Giddens, Anthony (1984a The Constitution of Society: Outline of the Theory of Structuration, Cambridge: Polity Press.

Giddens, Anthony (1990) The Consequences of Modernity, Stanford: Stanford University Press.

Giddens, Anthony (1991) Modernity and Self-Identity: Self and Society in the Late Modern Age, Stanford: Stanford University Press.

Gustafsson, Karl (2014) 'Memory Politics and Ontological Security in Sino-Japanese Relations,' Asian Studies Review 38(1): 71-86.

Hashimoto, Tom (2014) 'The Foreign Policy of Counter Secession: Preventing the Recognition of Contested States,' Europe-Asia Studies 66(9): 1578-1580. 
Hawkins, Robert L and Katherine Maurer (2011) 'YYou Fix My Community, You Have Fixed My Life': the Disruption and Rebuilding of Ontological Security in New Orleans,' Disasters 35(1): 143-159.

Herring, Eric (2000) 'From Rambouillet to the Kosovo Accords: NATO's War Against Serbia and its Aftermath,' The International Journal of Human Rights 4(3-4): 224-245.

Hiscock, Rosemary, Sally Macintyre, Ade Kearns and Anne Ellaway (2002) 'Means of Transport and Ontological Security: Do Cars Provide Psycho-Social Benefits to Their Users?,' Transportation Research Part D: Transport and Environment 7(2): 119-135.

Huysmans, Jef (1998) 'Security! What do You Mean? From Concept to Thick Signifier,' European Journal of International Relations 4(2): 226-255.

Jackson, Patrick Thaddeus (2011) The Conduct of Inquiry in International Relations: Philosophy of Science and its implication of world politics, London: Routledge.

Jeremić, Vuk (2008) 'Remarks Before the Foreign Affairs Committee of the European Parliament, 20 February,' available at http://www.kosovo.net/news/archive/2008/February_21/1.html (23 February 2014).

Jovanović, Bojan (2008) Prkos i inat: etnopsihološke studije, Beograd: Zavod za udžbenike.

Judah, Tim (2002) Kosovo: War and revenge, New Haven: Yale University Press. Kay, Sean (2012) 'Ontological Security and Peace-Building in Northern Ireland,' Contemporary Security Policy 33(2): 236-263. 
Ker-Lindsay, James (2012) The Foreign Policy of Counter Secession: Preventing the Recognition of Contested States, Oxford: Oxford University Press.

Ker-Lindsay, James (2013) 'Preventing the Emergence of Self-Determination as a Norm of Secession: An Assessment of the Kosovo 'Unique Case'Argument,' Europe-Asia Studies 65(5): 837-856.

Kierkegaard, Soren (1983) Sickness Unto Death, Princeton: Princeton University Press

Kinnvall, Catarina (2004) 'Globalization and Religious Nationalism: Self, Identity, and the Search for Ontological Security,' Political Psychology 25(5): 741-767.

Kissinger, Henry (2012) Diplomacy, New York: Simon and Schuster.

Koštunica, Vojislav (2008) Odbrana Kosova, Beograd: Srpska književna zadruga.

Krolikowski, Alanna (2008) 'State Personhood in Ontological Security Theories of International Relations and Chinese Nationalism: a Sceptical View,' The Chinese Journal of International Politics 2(1): 109-133.

Laing, Ronald (2010) The Divided Self: An Existential Study in Sanity and Madness, London: Penguin UK.

Lupovici, Amir (2012) 'Ontological Dissonance, Clashing Identities, and Israel's Unilateral Steps Towards the Palestinians', Review of International Studies 38(4): 809-833.

Marmor, Andrei (2009) Social Conventions: From Language to Law, Princeton: Princeton University Press.

Mattern, Janice Bially (2005) Ordering International Politics: Identity, Crisis and Representational Force, London: Routledge.

McSweeney Bill (1996) 'Identity and Security: Buzan and the Copenhagen School', Review of International Studies, 22 (1): 81-93. 
McSweeney Bill (1998) 'Durkheim and the Copenhagen School: a response to Buzan and Wæver ", Review of International Studies, 24 (1): 137-140.

McSweeney, Bill (1999) Security, Identity and Interests: a Sociology of International Relations, Cambridge: Cambridge University Press.

Mead, George Herbert (1934) Mind, Self, and Society From the Perspective of a Social Behaviorist, Chicago: University of Chicago.

Mearsheimer, John J (2001) The Tragedy of Great Power Politics, New York: WW Norton \& Company.

Mertus, Julie (1999) Kosovo: How Myths and Truths Started a War, Berkley: University of California Press.

Milić, Dejan A (2006) Srpski politički govor modernog doba, Beograd: Službeni glasnik.

Mitzen, Jennifer (2006a) 'Anchoring Europe's Civilizing Identity: Habits, Capabilities and Ontological Security, Journal of European Public Policy 13(2): 270-285.

Mitzen, Jennifer (2006b) 'Ontological Security in World Politics: State Identity and the Security Dilemma,' European Journal of International Relations 12(3): 341-370.

Mor, Ben D (2004) 'Strategic Beliefs and the Formation of Enduring International Rivalries: Israel's National Security Conception, 1948-56,' International Relations 18(3): 309-329.

Neumann, Iver B (1999) Uses of the Other:" the East" in European Identity Formation, Minnesota: University of Minnesota Press.

Neumann, Iver B and Jennifer M Welsh (1991) 'The Other in European SelfDefinition: an Addendum to the Literature on International Society,' Review of International Studies 17(4): 327-348. 
Neumann, Iver B. (2010) 'Entry into International Society Reconceptualised: the Case of Russia,' Review of International Studies 37(02): 463-484.

Noble, Greg (2005) 'The Discomfort of Strangers: Racism, Incivility and Ontological Security in a Relaxed and Comfortable Nation,' Journal of Intercultural Studies 26(1-2): 107-120.

Obradović-Wochnik, Jelena and Alexander Wochnik (2012) 'Europeanising the 'Kosovo Question': Serbia's Policies in the Context of EU Integration,' West European Politics 35(5): 1158-1181.

Padgett, Deborah K (2007) 'There's No Place Like (a) Home: Ontological Security Among Persons With Serious Mental Illness in the United States,' Social Science \& Medicine 64(9): 1925-1936.

Perritt, Henry (2010) The Road to Independence of Kosovo: a Chronicle of the Ahtisaari Plan, Cambridge: Cambridge University Press.

Qureshi, Emran and Michael Anthony Sells (2003) The New Crusades: Constructing the Muslim Enemy, New York: Columbia University Press.

Reckwitz, Andreas (2002) 'Toward a Theory of Social Practices: A Development in Culturalist Theorizing, European Journal of Social Theory 5(2): 243-263.

Ringmar, Erik (2007) Identity, Interest and Action: a Cultural Explanation of Sweden's Intervention in the Thirty Years War, Cambridge: Cambridge University Press.

Roe, Paul (2008) 'The Value of Positive Security,' Review of International Studies 34(4): 777-794.

Ruby, Keven G. (2004) Securitizing Terror: Ontological Security and the US Response to 9/11. Annual Meeting of the International Studies Association, Montreal, Quebec, Canada, March 172004. 
Rumelili, Bahar (2015a) 'Identity and Desecuritisation: the Pitfalls of Conflating Ontological and Physical security,' Journal of International Relations and Development 18(1): 52-74.

Rumelili, Bahar (2015b) Conflict Resolution and Ontological Security: Peace Anxieties, London: Routledge.

Sand, Shlomo (2010) The invention of the Jewish People, London: Verso Books. Sand, Shlomo (2012) The Invention of the Land of Israel: From Holy Land to Homeland, London: Verso Books.

Saunders, Peter (1989) 'The Meaning of 'Home'in Contemporary English Culture,' Housing Studies 4(3): 177-192.

Schmitt, Carl (2008) The Concept of the Political, Chicago: University of Chicago Press.

Silverstone, Roger (1993) 'Television, Ontological Security and the Transitional Object,' Media, Culture \& Society 15(4): 573-598.

Skey, Michael (2010) 'AA sense of Where you Belong in the World': National Belonging, Ontological Security and the Status of the Ethnic Majority in England,' Nations and Nationalism 16(4): 715-733.

Solomon, Ty (2013) 'Attachment, Tautology, and Ontological Security,' Critical Studies on Security 1(1): 130-132.

Šram, Zlatko (2009) 'Mentalitet nacionalnoga opsadnog stanja i predsjednički izbori 2008. u Srbiji,' Revija za sociologiju 40(1-2): 23-52.

Steele, Brent J (2007) 'Making Words Matter: The Asian Tsunami, Darfur, and "Reflexive Discourse" in International Politics,' International Studies Quarterly 51(4): 901-925. 
Steele, Brent J (2008a) 'Ideals That Were Really Never in Our Possession': Torture, Honor and US Identity,' International Relations 22(2): 243-261.

Steele, Brent J (2008b) Ontological Security in International Relations: Self-Identity and the IR State, London: Routledge.

Subotić, Jelena (2015) 'Narrative, Ontological Security, and Foreign Policy Change,' Foreign Policy Analysis. Article first published online: 23 January 2015.

Taylor, Scott (2000) INAT: Images of Serbia \& the Kosovo Conflict, London: Esprit de Corps.

Tillich, Paul (2000) The courage to be, New Haven: Yale University Press, 2000.

Vachudova, Milada Anna (2014) 'EU Leverage and National Interests in the Balkans: The Puzzles of Enlargement Ten Years On,' JCMS: Journal of Common Market Studies 52(1): 122-138.

Van Marle, Fenna and Shadd Maruna (2010) '`Ontological Insecurity'and 'Terror Management' Linking Two Free-Floating Anxieties,' Punishment \& Society 12(1): 7-26.

Vesti (2011) 'Ameri i Albanci nam najveći neprijatelji ' available at http://www.vestionline.com/Vesti/Srbija/145228/Ameri-i-Albanci-nam-najveci-neprijatelji (4 March 2015).

Vigilant, Lee Garth (2005) '“I Don't Have Another Run Left With It”: Ontological Security in Illness Narratives of Recovering on Methadone Maintenance,' Deviant Behavior 26(5): 399-416.

Wæver Ole, Barry Buzan, Morten Kelstrup and Pierre Lemaitre (1993) Identity, Migration and the New Security Agenda in Europe, London: Pinter. 
Walker, Rob BJ (1993) Inside/Outside: International Relations as Political Theory, Cambridge: Cambridge University Press.

Waltz, Kenneth (1979) Theory of International Politics, New York: Random House.

Webber, Mark (2009) 'The Kosovo War: a Recapitulation,' International Affairs 85(3): 447-459.

Wendt, Alexander (1994) 'Collective Identity Formation and the International State,' American Political Science Review 88(2): 384-396.

Wendt, Alexander (1999) Social Theory of International Politics, Cambridge: Cambridge University Press.

Wendt, Alexander (2004) 'The State as Person in International Theory,' Review of International Studies 30(2): 289-316.

White, George W (2000) Nationalism and Territory: Constructing Group Identity in Southeastern Europe, New York: Rowman \& Littlefield.

Young, Julian (2000) 'What is Dwelling? The Homelessness of Modernity and the Worlding of the World,' in Mark Wrathall and Jeff Malpas, ed., Heidegger, Authenticity and Modernity, 187-203, New Baskerville: Massachusetts Institute of Technology.

Zarakol, Ayşe (2010) 'Ontological (in) Security and State Denial of Historical Crimes: Turkey and Japan,' International Relations 24(1): 3-23.

Zaretsky, Eli (2002) 'Trauma and Dereification: September 11 and the Problem of Ontological Security,' Constellations 9(1): 98-105. 


\footnotetext{
${ }^{1}$ It is important to make a distinction between fear and anxiety. Fear is consciously organized concern directed at a precise externally threatening object which can be known and repelled. Anxiety is unconscious and emotive tension which is not oriented towards concrete threatening objects and which emanates from uncertainty (Giddens 1991: 44; Rumelili 2015b: 12).

${ }^{2}$ In Giddens' view, ontological security at the individual level is challenged as a consequence of modernity characterized by rapid and accelerating changes, separation of time and space, disembedding of social systems and reflexive reordering of social relations. The 'institutionalization of doubt', which is characteristic for high modernity, creates enormous potential for ontological insecurity. The only thing that protects humans from being engulfed with anxieties is the basic trust with origins in early childhood (Giddens 1990: 92-94).

${ }^{3}$ The referent object of societal security is collective identity. The concept of societal security was first developed by Barry Buzan as one of the five sectors - together with military, environmental, political and economic- in the widened security agenda (Buzan 1991). The concept was later appropriated by the Copenhagen School of Security Studies (Wæver et. al 1993, Buzan et. al 1998) and fiercely critiqued by Bill McSweeney for its objectivist and reified understanding of identity (McSweeney 1996, 1998, 1999). In order to conceptualize identity more reflexively, McSweeney draws on the concept of ontological security defined as 'the sense that the social order as practically conceived is normal, consistent with one's expectations and skills to go on in it' (McSweeney 1999: 156).

${ }^{4}$ Uriel Abulof uses the term 'epistemic insecurity' to denote this inability to know whether one's polity will exist in the future or not (Abulof 2015: 34).

${ }^{5}$ For an update on who recognized Kosovo and related statistics see: http://www.kosovothanksyou.com/ (accessed 29 March 2016).

${ }^{6}$ The term 'unilateral declaration of independence' is widely used to denote the fact that it was not agreed during UN-sponsored negotiations in Vienna (Perritt 2010: 94).
}

\section{Biographical note:}

Filip Ejdus is Marie Curie Research Fellow at the School of Sociology, Politics and International Studies (SPAIS), University of Bristol and Assistant Professor at the Faculty of Political Sciences, University of Belgrade.

\section{Acknowledgements:}

I thank Miroslav Hadžić, Jelena Subotić, Tim Edmunds and anonymous reviewers for their helpful comments on earlier drafts of this article. 